\section{Horticultural Industries in Arizona}

The growing and use of horticultural plants in Arizona is unique. Because of climate, scarcity of water, and consideration for the ultimate consumer, Arizona (Fig. 1) horticulture is different from that found in most states. Favorable climatic conditions allow for production of various fruits, nuts, and vegetables throughout the year, primarily for out-of-state markets. The shortage of water for crop production and landscaping is being overcome by proper management and plant selection. The expanding population of the state is increasing the demand for landscaping plants suitable especially for arid conditions, and facilities, such as golf courses and parks, for leisure activities.

The horticultural industries of Arizona are growing rapidly. Their character and importance are described in the following paragraphs. We think that you will agree that Arizona is an important horticultural state.

\section{GREEN INDUSTRY}

A warm climate and diverse topography combine to make Arizona a desirable place to live and visit. As a result, the state has experienced unprecedented population growth during the past decade, and tourism, particularly during the winter, is a major economic force. The increase in population and tourism has prompted the construction of appropriate facilities such as multifamily housing units, single-family residences, municipal structures, parks, schools, resorts, and golf courses. This construction has supported growth of the green industry, which includes florists, nursery and garden centers, greenhouse and field growers, landscape services, sod farms, and nursery sections of regional and national chain stores. The number of such firms increased $70 \%$ in just 5 years (19811986), while the number of employees and industry payroll more than doubled.

Decline of water resources has a major impact on the green industry. The state has established per capita consumption goals for the major metropolitan areas, and new developments are required to restrict landscaping to achieve these goals. Some communities are considering turf restriction ordinances, and resort golf courses are encouraged to use

Received for publication 24 Jan. 1990. The cost of publishing this paper was defrayed in part by the payment of page charges. Under postal regulations. this paper therefore must be hereby marked advertisement solely to indicate this fact.

Front cover: Picacho Peak. An Arizona landmark near the highway (I-10) between Tucson and Phoenix. In the foreground is the harvest of crisphead lettuce, a scene common to many fields in southern Arizona during the winter months, when the state is the leading supplier of lettuce to U.S. markets. reclaimed water. Growers have responded to the challenge by introducing and producing drought-resistant plant material. This has enabled them not only to meet the demands of the local market with unique specialty products, but to also begin expanding to other markets with similar water concerns, such as Las Vegas, Nev. Wholesale production, centered around the major metropolitan areas of Phoenix and Tucson, is estimated to be worth \$110 million, including \$20 million in shrub roses and $\$ 13$ million in turf sod.

Water resources also affect landscape architects, designers, and contractors. Most architects and designers incorporate xeriscape principles in their designs and contractors use the latest innovations to conserve water. Resort golf courses often use AZMET, a regional meteorological network, for irrigation scheduling. Landscape services account for more than one-half of total green industry sales, and was valued at \$247 million in 1986.

Most of the production and maintenance problems are typical for the arid southwestern United States. Caliche (indurated calcium carbonate), sodic soils, and water and soil salinity are all common, as are familiar insects and diseases, such as whitefly and Texas or cotton root rot (Phymatotrichum omnivorum).
Many people move to Arizona for allergy relief. Unfortunately, they often landscape their new homes with allergenic plants. High atmospheric pollen counts led Tucson to ban further planting of fruitless mulberry (Morus alba 'Striblingii') and olive (Olea europaea). Industry subsequently introduced a pollen-free olive cultivar, Swan Hill. Pollen production and potential allergenicity remain major considerations in plant selection.

A relatively new concern is the heat island effect-Phoenix may experience daytime highs of $60 \mathrm{C}$ on a routine basis in a few years. Reduced plantings designed to meet water conservation goals may exacerbate the situation, and the potential of desert trees and shrubs to alleviate these conditions and assist in atmospheric purification is receiving considerable attention. Tucson was one of the first participants in Global Releaf, with the goal of planting 1 million drought-resistant trees over a decade.

Arizona's green industry is highly educated, professional, and well-organized. Professional groups include the Arizona Landscape Contractor's Assn. (ALCA), Arizona Nursery Assn. (ANA), Arizona State Florists Assn., Arizona Society of Landscape Architects, Cactus and Pine Golf Course Superintendents Assn., the Central Arizona Landscape Maintenance Assn., and the western region of the International Society of Arboriculture. Certification programs exist in nursery operations, landscape maintenance, and arboriculture. Southwest Horticulture, a bimonthly magazine empha(continued on p. 498)

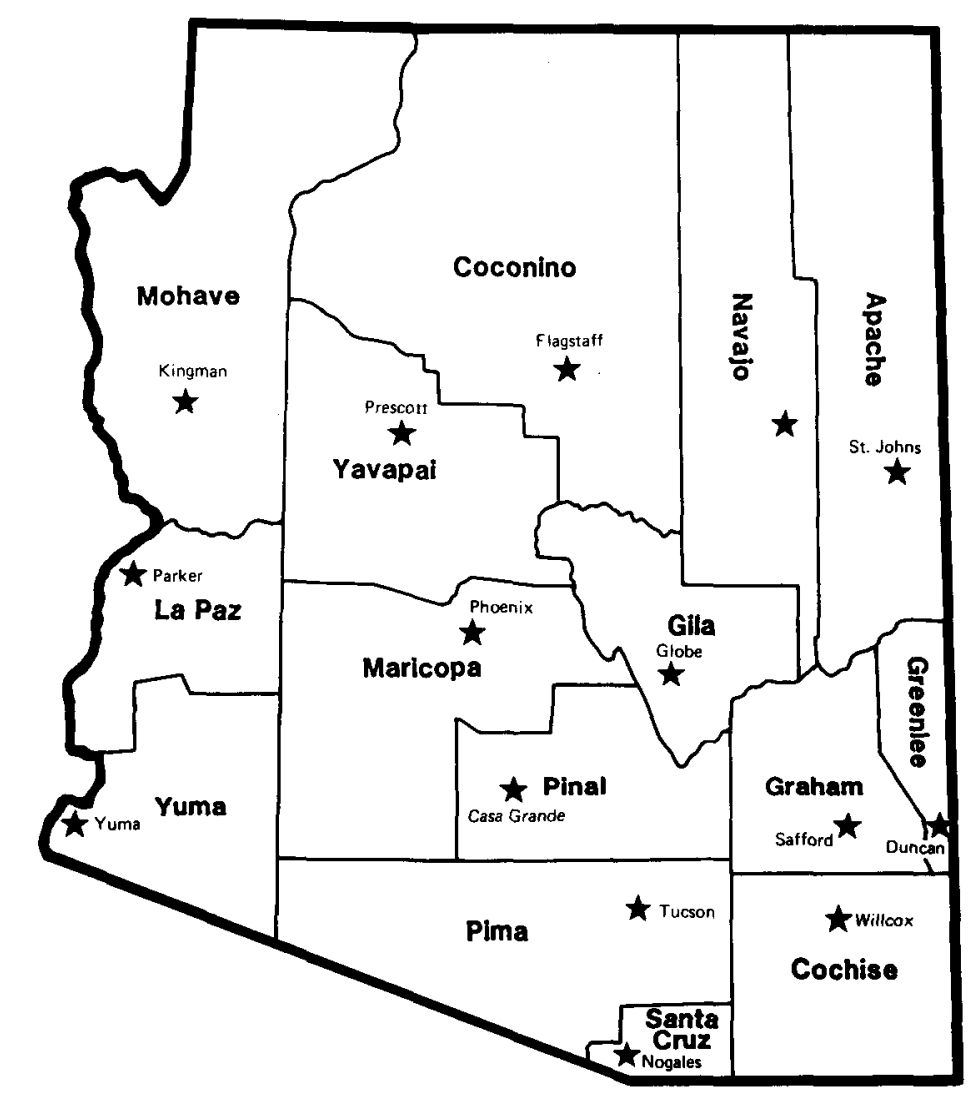

Fig. 1. Map of Arizona. 
too high or too low-at certain times of the year affect germination, plant growth, or harvest when one is trying to get a crop to come off in a certain market window. These adverse conditions are minimized through good management, resulting in microclimate modification and crop protection.

Many diseases and insects are problems. The most notorious of these in recent years is the sweetpotato whitefly (Bemisia tabaci Genn.), which is the vector for lettuce infectious yellows virus (LIYV). Serious losses have occurred in fall lettuce from LIYV, causing prices to skyrocket. In Nov. 1987, Yuma lettuce prices (FOB) ranged from $\$ 24$ to $\$ 27$ per carton of 24 heads. Such prices contributed to a record year for income.

Lettuce is Arizona's leading vegetable. In 1987-88, although somewhat an abnormal season in relation to price, because of lettuce yellows, the lettuce crop was worth $\$ 333$ million. This was mostly crisphead; however, other lettuces are becoming important because of emphasis on mixed loads. The Arizona production season is from about 1 Oct. to 15 June, spread over several localities from Yuma to Willcox. During the winter, the Yuma area is the chief supplier of lettuce to U.S. consumers, earning it the title of "Winter Lettuce Capital of the World". For the 1989-90 season, it is estimated that Arizona will have more than 26,300 ha of lettuce.

Melons as a group are next to lettuce in importance. Cantaloup, watermelons, honey dews, and mixed melons are available from June to November. Principal producing counties are Maricopa, Pinal, La Paz, and Yuma. Seedless watermelons have attracted attention in the past few years.

Cauliflower and broccoli production has expanded rapidly in recent years; hectarage of these crops has been increasing at the rate of $8 \%$ each year. Harvest occurs mainly from November to April. Yuma and Maricopa Counties are the main producers.

Arizona's potato harvest is from May to July. The crop is noted for its high quality for making chips. Some reds and russets are grown for table use. Main producing areas are in eastern and western Maricopa County.

Many other crops are of lesser hectarage but contribute significantly to the vegetable industry. Among these are asparagus at Yuma, chili peppers in Cochise County, and carrots, tions for growing vegetables, it is not out problems. Salinity is forever present in the soil and water. Temperature extremes- onions, and mixed greens in several localities. Speciality items such as bok choy, napa, rapini, and green onions are important for some growers.

Processing is of minor importance in the state; however, a few vegetables enter this market-early tomatoes for canning, chili peppers for dehydration and canning, onions and garlic for dehydration, and cucumbers for pickling.

The western Mexico vegetable industry has an impact on Arizona. The marketing agencies for the vegetable growers of the Mexican states of Sonora and Sinola are located in Nogales, Ariz. This industry supplies nearly half of the vegetables consumed in the United States during the winter, and most of this produce comes through Nogales. On busy days, 600 to 700 trucks cross the border into Arizona. Although vegetables from Mexico such as tomatoes, peppers, and cucumbers do not compete directly with Arizona crops, others such as asparagus, green onions, cauliflower, broccoli, lettuce, and cantaloup do. At these times, however, Arizona shippers complement their marketing program with supplies from Mexico.

Arizona vegetables are grown chiefly in a geographical zone referred to as the Sonoran Desert. The Sonoran Desert also encompasses parts of southern California and northern Mexico. When the vegetables of the entire desert region-Arizona, California, and Mexico-are considered, one has to conclude that this is one of the most important vegetable-producing areas of the world.

\section{COMMERCIAL FRUIT AND NUT PRODUCTION}

Arizona currently ranks ninth in the United States in combined fruit and nut production, with a farm value of about $\$ 145$ million $(\mathrm{Ta}$ ble 2). This production comes from 30,375 ha of established orchards and vineyards. The fruit industry is diverse, ranging from subtropical, low desert, tow-elevation (citrus) to temperate, high desert high-elevation (apples) climates. During any month of the year, a particular fruit or nut is being harvested, processed, and shipped.

Most of the fruit and nut production is located in the southern third of the state and is shipped out-of-state to high-population areas. The lack of adequate rainfall requires that all plantings be irrigated on a regular basis. Irrigation systems vary with crop and water source. The local microclimate dictates the kinds and cultivars of fruit grown. Important microclimatic factors include extreme winter and summer temperatures, frequency of killing frost, length of the growing season, and chill unit accumulation.

The low desert elevations of Maricopa and Yuma Counties are ideally suited for citrus production. Citrus is Arizona's largest fruit industry in terms of hectarage $(15,400)$ and value ( $\$ 90$ million). Even though citrus types are grown throughout the low desert, the warmer areas of Yuma County are well-suited to lemons and some grapefruit. The Colorado River is the primary water source for irrigation. Other citrus types, such as sweet 
Table 2. Fruit and nut production.

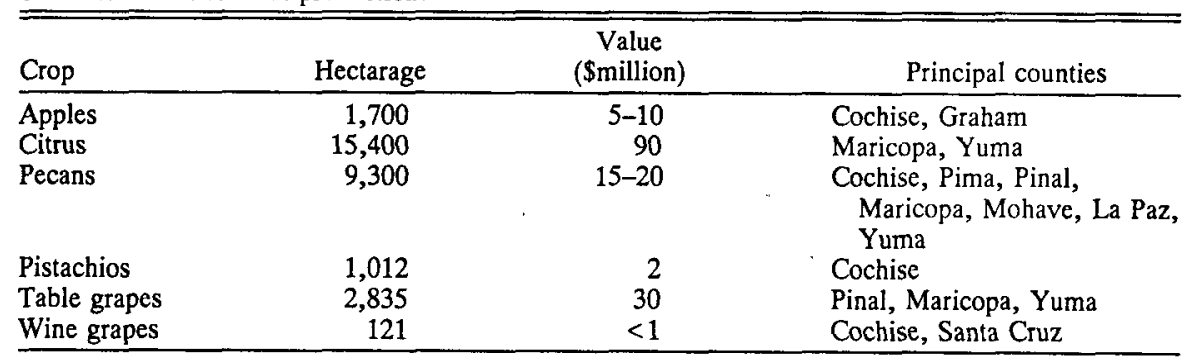

oranges; navels, grapefruit, and tangerines are concentrated in Maricopa County both to the east and west of Phoenix. Packing houses are abundant, as much of the fruit enters into both domestic and foreign markets. Urbanization is a constant threat to orchard decline in both counties; however, new groves, with more exotic cultivars, are being established in rural areas.

The low desert is also the home for table grape, raisin, and low-chill stone fruit industries. The table grape industry is located in Pinal, Maricopa, and Yuma Counties and is composed of seedless cultivars that have multiuse characteristics; i.e., table, raisins, and juice. In 1987, about 2850 ha of 'Thompson Seedless', 'Flame Seedless', and 'Perlette' grapes were grown for table use, with a farm value of $\$ 30$ million. This past year, 810 ha were converted to growing raisins, with the concurrent establishment of a processing plant. This conversion demonstrates the flexibility of this industry to meet economic demands.

The low-chill fruit industry is small compared to citrus and grapes, but provides fruit for the early season market (May). Small, but productive, apricot and peach orchards are distributed from eastern Maricopa County to western Yuma County. Featured cultivars include 'Flordaprince', 'EarliGrande', and 'Katy'.

The high desert elevations of Cochise and Santa Cruz Counties provide the chilling and cooling effect for apples, cherries, peaches, and wine grapes. The apple industry, located in the Sulfur Springs Valley in Cochise
County, had its beginning in the late 1970s, with the planting of traditional cultivars such as 'Delicious' and 'Golden Delicious'. At that time, 'Granny Smith' (GS), a new cultivar, was widely planted because of the long growing season inherent to southeastern Arizona. GS accounts for one-half of the 1700 ha now planted. In recent years, 'Gala' and 'Fuji' have been planted and grafted, as they seem to be ideally suited to this mountain valley. As one would expect, orchard systems vary with each grower. Orchards can be observed as freestanding, vertical trellis (two to six wires), and ebro. Tree densities vary from 500 to 2000 trees/ha. In 1989, about 1 million boxes were packed and shipped into domestic and foreign markets. Cull fruit generally enter the by-product juice plant located in the valley.

Arizona is not without its wine. The cool nights and warm days of the higher-elevation ranges are ideal for growing premium Vinifera wine grapes. This industry, in its infancy, has thrived since 1982 with the development of four wineries to support a modest 121 ha. Water-harvesting techniques are ever popular for hillside vineyards, and all vineyard irrigation is by the drip method. Major cultivars include 'Cabernet Sauvignon', 'Chenin Blanc', and 'Sauvignon Blanc'.

Nuts are an important segment of Arizona's new crop concept. Arizona ranks fourth in the United States for pecan production and both low and high desert conditions and must be heavily irrigated to maintain tree growth and nut quality. Producers market their prodsecond for pistachio. Pecans are adapted to uct across the pecan belt as well as to a local processor. Arizona has the privilege of having the largest contiguous pecan orchard in the world. Average yields of $0.38 \mathrm{t} \cdot \mathrm{ha}^{-1}$ are considered excellent, making Arizona a leader in the industry.

After a struggling beginning, the pistachio industry has blossomed into one of the leading crops in terms of economic returns. The high desert conditions of the Sulfur Springs Valley are well-suited in terms of chilling and length of growing season. The 454,000 $\mathrm{kg}$ produced from 810 ha in 1989 was processed by three local plants. Arizona pistachios are shipped into domestic and foreign markets.

\section{AN INVITATION}

We extend an invitation to you to attend the 87th ASHS Annual Meeting in Tucson, Ariz. 4-8 Nov. 1990. We hope that you can spend a few days before or after so that we can show you the horticulture of Arizona. Watch for information on tours in future issues of the ASHS Newsletter and HortScience.

\section{NORMAN F. OEBKER MiCHAEL J. KILBY JIMMY TIPTON \\ Extension Horticulturists Dept. of Plant Sciences Univ. of Arizona \\ Tucson, AZ 85721}

Back cover: Boyce Thompson Southwestern Arboretum. A view of various species of native plants in gardens founded in the 1920s by William Boyce Thomspon at Superior, Ariz. Plantings include more than 1500 different desert plants collected worldwide in various outdoor settings and greenhouses. The arboretum is for study as well as for show, with emphasis on developing the usefulness of plants for arid lands. Nature trails, beginning at the Visitor Center, wind through 14 ha of grounds. Open daily (except Christmas) from 0800 to $1700 \mathrm{HR}$. The arboretum is located $\approx 5 \mathrm{~km}$ west of Superior, off U.S. 60, $96 \mathrm{~km}$ southeast of Phoenix and $158 \mathrm{~km}$ north of Tucson. 